DOI: 10.2478 /ausp-2050-0012

\title{
Elements of Humour in the Classroom A Qualitative Approach to Data
}

\author{
Erika-Mária TÓDOR \\ Sapientia Hungarian University of Transylvania (Cluj-Napoca, Romania) \\ Department of Human Sciences, Miercurea Ciuc \\ todorerika@uni.sapientia.ro \\ Enikő TANKÓ \\ Sapientia Hungarian University of Transylvania (Cluj-Napoca, Romania) \\ Department of Human Sciences, Miercurea Ciuc \\ tankoeniko@uni.sapientia.ro
}

\begin{abstract}
Neither grades nor formal indicators of teachers' effectiveness measure the presence or the nature of humorous situations in classroom conversations although these situations are, in fact, the iceberg components of the teacher-student communication and are important indicators of the motivational-behavioural background as well as cohesion of the group, of the power of collective thinking and creativity inside class community.

The role of humour has not always been positive throughout time. For example, according to Stanford Encyclopedia of Philosophy (2016), Plato was one of the most influential critics of laughter, and he treated it as an emotion that overrode rational self-control, and thus could be considered a certain kind of evil. As for the bad reputation of humour, we can find yet another face of this reality in Kant's approach, according to which humour can be understood as play, while laughter is a play signal.

The present research is looking for answers regarding the role of humour in classroom conversation and interaction, according to students' opinion, how they interpret certain terms related to humour, and what humorous situations they report of. In this study, we present the data of an empirical research based on the questionnaires completed by 159 students in the $5^{\text {th }}$ to $8^{\text {th }}$ grades from both urban and rural area, data which have been processed with the help of MAXQDA. Due to the highly practical nature of the research, it presents a general picture of the characteristics and role of humorous classroom situations.

This unique location offers a specific interpretation of the discourse of humour, based on local and individual life experiences.
\end{abstract}

Keywords: humour, classroom discourse, qualitative data analysis 


\section{Introduction}

Defining the notion of humour is a complex and risky undertaking as the discourse of humour is to be interpreted by taking into consideration a number of influencing factors: the characteristic of the speaking situation, the personality of the transmitter and that of the receptor, the nature of their interpersonal relationship, culture, customs, the historical time, etc. At the same time, humour is quite often associated with the notions of joke, irony, mockery, satire, or playfulness, though these are not very closely related terms. Mixing them up would lead to erroneous meaning associations.

The complexity of defining humour can be traced in different dictionaries as well. The Dictionary of the French Language (Dictionnaire de la Langue Francaise) ${ }^{1}$ defines the term in the following way: 1 . Those dominant dispositions which make up the temperament. 2. Temper, temperament. 3. Attitude without reflection. 4. A state at a given time which is not the building stone of the human character. According to the Cambridge Dictionary, humour is "the ability to find things funny, the way in which people see that some things are funny, or the quality of being funny". The Explanatory Dictionary of the Romanian Language (Dictionar explicativ al limbii române) ${ }^{2}$ defines humour as: 1 . Inclination towards jokes and irony, hidden underneath an apparent seriousness, which appears in words or in writing, e.g. cheerfulness, fun. 2. An aesthetic category belonging to the comic, its point being to underline the incompatible and absurd side of certain natural situations. According to the Explanatory Dictionary of the Hungarian Language (A magyar nyelv értelmezó szótára), ${ }^{3}$ humour is: 1. [...] the totality of moistures which circulate in the body, having an influence on the mood of the individual. 2. Cheerful, joyous mood which appears in witty waggery though covered by a certain level or seriousness. 3. Sensibility and disposition to waggery, to joke, to a generally cheerful and joyous outlook on things, on the world.

In the definitions provided above, it is clearly visible that humour appears in different culture-specific paradigms (which, from the perspective of translatability, take us into the territory of realia). The most important features of humour seem

1 Humeur 1. Ensemble des tenancies dominantes qui forment la temperament, 2. Naturel, temperament, 3. Comportament irréfléchi, 4. Dispozition momentanée quine constituie pas un trait de caractère.

2 Umor 1. Înclinare spre glume şi ironii, ascunse sub o aparență de seriozitate; manifestare prin vorbe sau prin scris a acestei înclinații; veselie, haz. 2. Categorie estetică aparținând sferei comicului a cărei esență constă în sublinierea incompatibilității şi absurdității laturilor unor situații considerate fireşti.

3 Humor 1. [A régi orvosi felfogás szerint] az emberi testben keringô, a testet fenntartó azon nedvek összessége, amelyeknek az egyén kedélyvilágára lényeges hatásuk van. 2. Olyan derûs v. vidámnak látszó kedélyállapot, amely szellemes tréfálkozásban nyilatkozik meg, de valójában bizonyos fokú komolyságot leplez. 3. Érzék, hajlam a tréfálkozásra, a kedélyességre, a dolgok vidám, derûs szemlélésére. 
to be: originality, incongruence, surprise, aggression, emotional transformation, apparent difficulty in comprehension (Veatch 1998), sociocultural knowledge, phonetic, lexical, structural, referential ambiguity in verbal humour, syntagmatic relationships, and figurative language use (with hyperbole, metaphors, simile, zeugma) (Raskin 1985).

Humour is in close connection with laughter and smiling. Although man salutes his coming into this world by crying, under similar circumstances we all seem to be alike in various forms with regard to laughter as well. Both laughter and crying have biological roots and both are determined by community experiences, the web of intersubjective relationships, and the sum of attitudes towards the Other, as non-Self. While crying is associated with some feeling of discomfort, smiling and laughter are to be interpreted as closely related to well-being (Berger 2017, Bagdi and Pap 2011).

\section{Interpretations of humour over time}

Although we treat laughter and humour, similarly to crying and sadness, as natural phenomena which accompany our lives, over time, there have been various attitudes towards judging these manifestations. In order to have a broader view of the topic, philosophical writings offer us an extensive picture. In this regard, it is worth considering approaches available in the literature which will be presented based on Stanford Encyclopedia of Philosophy (Morreall 2016) in what follows.

\subsection{Bad perception of humour}

Until the $18^{\text {th }}$ century, the term humour has been used with a different meaning as opposed to its current sense, which can be associated with fun and laughter. Although major philosophers have approached laughter, they mainly discussed it related to some other topic. Henri Bergson's book entitled Laughter published in 1900 was the first book on humour written by a notable philosopher.

One of the most well-known Ancient Greek philosophers, Plato, considered laughter to be a malicious attitude since it overrides rational self-control. Other Greek thinkers thought the same and had objections to laughter and humour. Although Aristotle saw wit as a valuable part of conversation (Nicomachean Ethics 4,8 ), he shared Plato's view that laughter expresses scorn and insolence.

Early Christian thinkers in the later European culture followed in this line of thinking. Moreover, negative representations of laughter and humour in the Bible lead to further distancing from humorous situations. In these thinkers' view, laughter equalled hostility, loss of self-control, irresponsibility, lust, or anger. Rejection of laughter and humour continued throughout the Middle Ages, as well. 
Later, Puritans too condemned humour. In this period, a number of tracts against laughter and comedy appeared. Well-known philosophers of the time, such as Thomas Hobbes or René Descartes, had their own fight against laughter. For example, in Passions of the Soul, Descartes claims that laughter accompanies three of the six basic emotions: wonder, love, (mild) hatred, desire, joy, and sadness. However, he sees laughter only as an expression of scorn and ridicule.

\subsection{The Superiority Theory}

The Superiority Theory of humour can be traced back to the Ancient Greek philosophers, who considered that a person laughs about misfortunes of others because these misfortunes point out the person's superiority on the background of shortcomings of others. For example, people laugh at inferior or ugly individuals because they feel a joy at feeling superior to them. In this respect, the feeling of superiority is born from inadequacies inside of a group or a deviation from the norm within the community.

The theory works the other way round, too. Sometimes we laugh when a comic character shows surprising skills that we lack. For example, in the silent movies of Charlie Chaplin, the main character is often found in a desperate situation in which he seems lost. But then he manages to escape performing an unexpected stunt which the viewer would have never thought of, much less, could ever perform. Laughing at such situations we do not find ourselves superior. It is the character that we laugh about that appears to be superior.

\subsection{The Relief Theory}

According to the Relief Theory, humour and laughter work as a pressure-relief valve on a steam boiler with respect to our nervous system. In 1709, in his work entitled An Essay on the Freedom of Wit and Humour, Lord Shaftesbury uses the term humour in its modern sense of funniness. Until then, scientists considered that nerves carried "animal spirits" (as illustrated by some of the definitions of humour in French, Romanian, and Hungarian in the Introduction). Later, with the discoveries of Herbert Spencer or Sigmund Freud, the Relief Theory maintained the idea that laughter relieves repressed nervous energy.

Contemporary scholars think that the hydraulic model of the nervous system put forward by the Relief Theory is outdated. More generally, philosophers and psychologists studying humour nowadays avoid using the Relief Theory as a general explanation of laughter or humour. 


\subsection{The Incongruity Theory}

Another point of view which challenged the Superiority Theory in the $18^{\text {th }}$ century was the Incongruity Theory. As opposed to the Superiority Theory, which claims that laughter is caused by feelings of superiority, the Incongruity Theory states that laughter occurs because we perceive something incongruous, something which is beyond the regular patterns or expectations. The approach was supported by wellknown philosophers of the time such as Kant, Schopenhauer, or Kierkegaard.

Kant located the incongruity in humour between our expectations and our experience, while Schopenhauer visualized it between our sense perception over real things and our abstract rational knowledge of the same things. Using this view on the discrepancy between abstract ideas and real things, Schopenhauer manages to explain the offensiveness of being laughed at, the kind of laughter found at the heart of the Superiority Theory. Kierkegaard thought the essence of humour was in the contradiction between what we expect and what we experience. In his acceptance, the violation of one's expectations is the key element of the tragic as well as the comic.

\subsection{Humour as play and laughter as play signal}

Very few philosophers have affirmed that humour is a kind of play. Among those few to look at humour as a play and value its mental side was Thomas Aquinas. According to his view, if a person is never playful or humorous, he acts "against reason", and thus he is guilty of a vice. Later, in 1999, Ted Cohen wrote about the social benefits of joke telling, and in the $20^{\text {th }}$ century many psychologists confirmed Aquinas's view of humour as something virtuous.

In today's perception, humour promotes tolerance for ambiguity and diversity and promotes creative problem solving. It reduces negative emotions when it comes to situations which involve announcing bad news, apologizing, complaining, warning, criticizing, or commanding. It induces trust, reduces conflict, and also brings delight.

\subsection{Comedy}

Humour and laughter have been closely related to the genre of comedy since the Antiquity. Comedies, as opposed to tragedies, reach the experience of catharsis in a distinct way. However, comedies and tragedies share several common features, as described in the Stanford Encyclopedia of Philosophy:

Where they differ is in the responses of the lead characters to life's incongruities. Identifying with these characters, audiences at comedies and tragedies have 
contrasting responses to events in the dramas. And because these responses carry over to similar situations in life, comedy and tragedy embody contrasting responses to the incongruities in life. (Morreall 2016: n.p.)

\section{Sources of humour}

According to Ribot (1900: 355), "humour is a psycho-physical phenomenon writ large, of which laughter is the physical aspect". Expectedly, the causes of laughter can be various. One of the many reasons which trigger laughter quite frequently is humorous stimuli. When describing humorous circumstances which would be seen as stimuli to provoke laughter, Kline (1907, see Martin 2007) points it out that rhythmical movements in nature cannot trigger humour. In turn, mimicry (e.g. puppet shows or pantomime), awkwardness (e.g. way of dressing), the wrong use of objects (e.g. somebody fighting with a spoon), serious actions occurring out of time or out of place (e.g. silent movies with Charlie Chaplin) as well as manner (e.g. an adult behaving like a child), words or language (e.g. foreign accent or mispronunciation) can be actual sources of humour.

Interpreting humour is influenced by a number of factors: we have to take into consideration the speaking context, the person of the transmitter and that of the receptor as well as the nature of their relationship but also common knowledge, culture, customs, the historical time, etc. Sometimes even the mood of a person can modify the way one interprets a humorous situation. "Sometimes an event which under normal circumstances would be seen as humorous will not be so interpreted because of an intervening physiological or psychological process or state. [...] Even people with a "good sense of humor» will occasionally be immune to humor because they are in a bad mood" (LaFollette and Shanks 1993: 331).

\section{Does humour have its place in schools?}

Classroom interaction differs significantly from the features of everyday speaking situations, and thus it presupposes characteristic methods of analysis. Classroom talk is an occurrence of conversational discourse with rigid norms of interaction, and it is highly structured and routinized. According to Hinkel (2006: 472), investigation in different locations in different countries around the world pointed out that "in classroom interaction, teachers talk approximately $75 \%$ of time, with the remainder divided among the students". Although we are talking about a wellstructured speech act, several factors lead to the conclusion that playfulness, the creative humour, and learning situations built on these are the very factors which define teacher effectiveness (Douglas and Sass 2009). 
Classroom conversation represents the specific form of the creation of meaning as it is planned, guided, and goal-oriented. It is made up of a set of subsequent goaloriented conversations (the parallel symbiosis of the language of instruction and, occasionally, the vernacular language), which are structured by the short- and longterm goals. Teachers work out various individual strategies in order to organize learning, and, fundamentally, this is what makes a class effective or not (Bannink and Dam 2006).

In this context, the humorous nature of different situations is defined by the teacher, by the student, by the tools (i.e. school books) as well as by the interaction between them. As we are discussing about certain goal-oriented, planned learning situations, the potential appearance of humour is carried first of all by the personality of the teacher but also by the characteristics of the teacher-student relationship. The emerging humour can be linked mainly to the spontaneous speaking situations and can be interpreted in correlation with creativity, critical thinking, communication, and cooperation. Thus, humorous elements are to be captured in a context which is well-organized, planned, and its main goal is usefulness rather than pleasure.

It is a well-known fact that humorous creativity is defined by the level of command of a language and the practice in the use of a language. According to Wulf (2010), one has a good command of a language if they understand its humour, if they can express humour in that particular language. It often requires sophisticated linguistic, social, and cultural competence - "humour helps us win friends or a mate, disarm enemies with a retort, defuse tension in a delicate negotiation, or persuade others to our point of view" (Wulf 2010: 156).

In a survey examining the use of humour in tests, McMorris, Boothroyd, and Pietrangelo (1997, cited by Wulf 2010: 156) conclude that humour seems to reduce stress caused by the test situation rather than improve test performance. And although humour is a defining component of human nature, one of the sources of joy, in order to evolve, it needs emotional safety which allows the humorous breakout. In one of his interviews, Péter Medgyes (2018) points it out that the humorous characters of older language course books, through whose adventures many instances of grammatical terminology and vocabulary items have been introduced, are about to disappear. He mentions characters like Arthur in Access to English (Coles and Lord 1974) or the adventures of a Hungarian boy in the French series of course books written by Pál Pataki (1979-1982).

\section{Previous research on classroom humour}

There have been very few articles dealing with research on humour in school or classroom humour though many school adventures or recollections can be grouped into humorous narratives. The enduring nature of these memories is defined by 
certain functions. According to Orme (1986), humour used in instruction can have several reasons such as the ones enlisted in what follows: (1) to motivate, (2) to build learner attention and positive expectations, (3) to help instructors and learners break free of constraints, (4) to use intellectual play as a precursor to concept development, (5) to develop group cohesiveness, confidence, and identity, (6) to effect learning, (7) to create variations in pace and reinforcement, (8) to enhance the desire to teach, (9) to increase instructor credibility, and (10) to control your own folly. Furthermore, Ron (2000: 20-28) argued that use of humour in the classroom can help to create a more positive learning environment, can break down barriers of communication between the teacher and the students and help them to retain subject matter, to attend class, to increase comprehension and cognitive retention.

We have knowledge of an extremely reduced number of studies dealing with humour in schools in Romania. For example, Tutunea's article (2020) is based on a research observing audio-recorded lessons with students aged 9-12. The author follows the manifestations of humour in classroom conversations, and she makes a clear distinction between humour of exclusion (e.g. irony, ridicule, sarcasm, audacity, satire) and the techniques of humour of inclusion (e.g. self-deprecation, displacement, play upon words, confusion). Based on her data, she reaches the conclusion that in classroom conversations we can distinguish between intentional or unintentional situations, and humour most often occurs in intentional situations. Most frequently, it is generated by teachers (67\% of the situations) and only rarely by students (33\% of the situations). She concludes that the humour which occurs in classroom is mostly innocent and "is oriented towards relaxing the atmosphere [...] and drifting the main course of the conversation" (Tutunea 2020: 165).

Understanding the question thoroughly presupposes, on the one hand, linguistic, research-related approaches and, on the other hand, tools related to pedagogy, to organizing learning, that is, an interdisciplinary view of the topic. So far, in analysing classroom discourse, the focus has been on analysing conversations and ethnographic approaches (Harklau 2005) since in this context the exploration of the spoken discourse, language, and the structure of interaction in schooling can be interpreted in their interaction. At the same time, in this respect, we can distinguish between several independent variables (Ezechil 2002) such as factors specific to different school subjects, variables connected to the personality of the teacher or group dynamics, etc. The research to be presented in this study has been analysed from the perspective of students in the $5^{\text {th }}-8^{\text {th }}$ grades, and we were really curious about students' opinion on the humorous aspect of school life, what situations they considered humorous, what school experiences they evoked when thinking of a humorous situation, what the role of these humorous moments was, and when they thought a classroom situation was humorous. 


\section{The empirical research}

In order to get a thorough picture of the phenomenon, we have applied a questionnaire in paper format, carried out in writing, containing three closed questions (referring to general information about the features of the sample establishing respondents' gender, age, and class), one multiple choice question (referring to the frequency of humorous situations in classroom context), and five open questions. This latter set of questions inquired respondents about advantages and disadvantages of classroom humour, asked them to describe their perspective on the profile of a humorous teacher, their experience with the most humorous situation in the classroom as well as the difference between humour and mockery.

The role of the set of five open questions was to provide a frame for evoking experiences and reflecting over them. In this latter part, we can speak about a supported recollection of individual attitudes and opinions, stories related to the main topic. When designing data collection, we had in mind students' individual traits; that is why we aimed at preparing them for more elaborate, free answers by starting off with a number of closed questions. Thus, we have been provided with a broader view on how students reflect on classroom conversations, different classinternal events and experiences.

Data was analysed on a textual level by using inductive logic, and then it was modelled on the level of terms; finally, term webs were designed using MAXQDA (demo version), a qualitative data analysis program (Sántha 2015, 2013; ${ }^{4}$ Mackey and Gass 2005).

Having a thorough survey in mind, data processing started with coding. First, we determined the primary codes and then attached secondary codes to them. So, for example, in the case of statements highlighting a positive atmosphere, we used the term Flow, while we attached the code Efficiency to opinions which could be related to effective learning (e.g. a deeper understanding, retention into the longterm memory).

We have also assigned secondary codes in cases where the answers imposed it. For instance, in the case of group laughter, which was perceived as experiences inside the community, we indicated a secondary code referring to the positive effect of the mentioned experience (see Figure 2. It lightens the class; it dissolves monotony, the routine; the atmosphere of the class changes; it dissolves rigour, "so that we don't just sit quietly but smile a bit"). To avoid subjectivity, there has been an intracoding as well so that we could check the validity of the various categories.

The research involved 159 students in the $5^{\text {th }}-8^{\text {th }}$ grades from schools where the language of instruction was Hungarian: 81 girls and 78 boys, aged between 11 and 14. We have chosen a school from an urban area and another from a rural area and

$4 \quad$ I would like to express my gratitude to Dr Kálmán Sántha for introducing me to using MAXQDA and its methodological possibilities. 
asked for the opinion of 58 students from a village and of 101 students from a small town regarding their experiences related to classroom humour. As understanding and experiencing humour depends on a number of distinctive factors, we have chosen primarily to interpret the collected research data qualitatively. Thus, the data summed up offers a snapshot of the phenomenon under discussion. Hereby, we have addressed the characteristics of the kind of norm system which is created by micro-communities in schools related to the discourse of humour inside the community.

\section{What is the role of humour in schools?}

\subsection{Presenting the data}

In analysing classroom interaction, we can focus on several factors. The literature (Levine 2011: 105) mentions the following: significance, activity, identity, relationship, approaches to educational policies and organizing learning as well as correlation between languages and linguistic systems.

We asked students involved in the empirical research to signal whether there were any humorous situations in their school lives and everyday classroom existence and to state how frequent these situations were. Their answers are summarized in the diagram below. Sometimes and often turned out to be the most common answers.

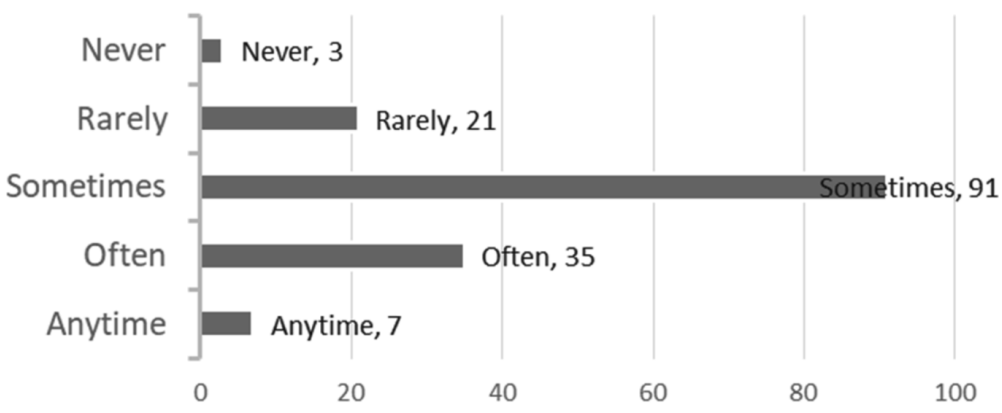

Figure 1. Humour in the classroom $(N=159)$

Since we have undertaken to map humorous elements in goal-oriented speech situations, we were curious whether students thought that humour had its place in such an environment and what roles these humorous situations played if they implied any advantages or disadvantages. We focused on highlighting key terms in the opinions provided by the students (as illustrated in tables 1 and 2) and based on those modelling term webs (as illustrated in figures 4 and 5). 
Table 1. Primary and secondary codes of the data. Functions of humour

\begin{tabular}{lc}
\hline Code system & Frequency \\
\hline Discourses of humour & 155 \\
\hline Community experience & 31 \\
\hline Positive experience & 37 \\
\hline Efficiency & 21 \\
\hline Flow & 54 \\
\hline Time management & 4 \\
\hline Subjective time & 8 \\
\hline
\end{tabular}

Table 2. Primary and secondary codes of the data. Drawbacks of humour

\begin{tabular}{lc}
\hline Code system & Frequency \\
\hline HUMOUR in the classroom & 157 \\
\hline Conflict & 0 \\
\hline Time management & 22 \\
\hline Self-control & 17 \\
\hline Bad assessment & 31 \\
\hline Abuse-offence & 32 \\
\hline Efficiency & 44 \\
\hline
\end{tabular}

Based on the experience of the respondents, classroom humour ensures a more intense living of the Presence, the code terms of which are displayed in the term web in Figure 2.

This living of the presence becomes concrete through the subjective time (since time passes differently, even more quickly) on the one hand, while respondents referred to the quality of time and its effect on the individual (we get into a better mood, the teacher becomes more cheerful) on the other hand. In a nutshell, here they refer to the flow, i.e. experiences with a positive nature they were involved with. Positive experiences associated with humour strengthen the endurance of learning by making it more playful. The answers provided by respondents outline a third dimension, which refers to an emotional-attitudinal background: a realm where they can laugh, where they can relax, a place without discomfort or fear. Thanks to laughter, students feel "they are not in a prison" (quote from one of the respondents' answer) - laughter is the condition of liberation. At the same time, laughter has also a team-building role: "a little bit of laughter brings the team together", "makes children be better", and "if students are happier, their happiness brings about a better performance". 


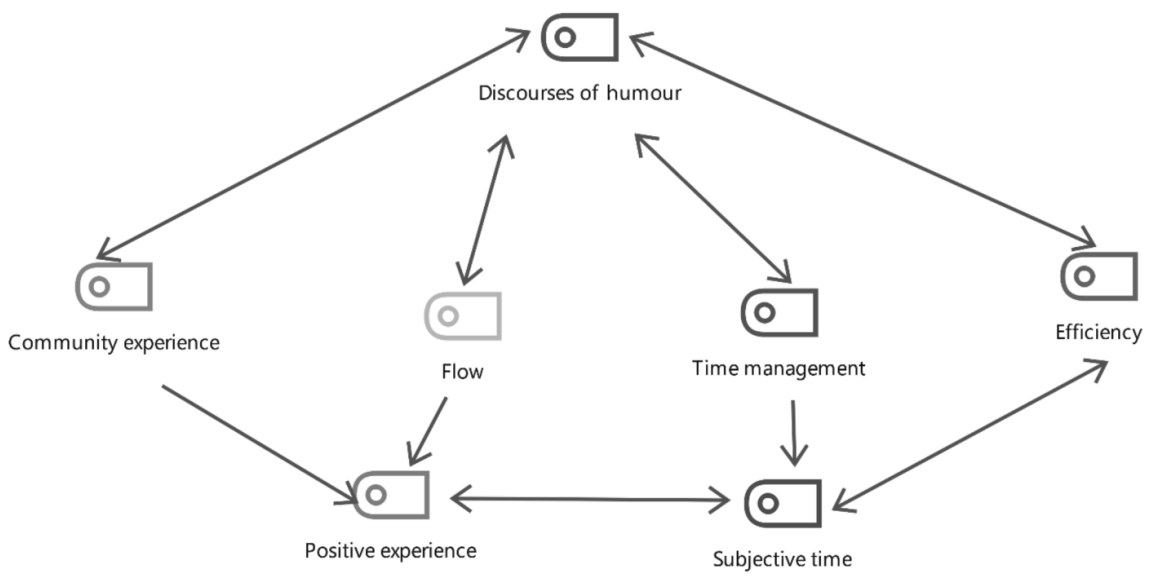

Figure 2. Term web on classroom humour from students' perspective

The respondents relate the seamy side of humour to a decrease in learning efficiency. In this context, moderation plays a central role (see Figure 2). Lack of moderation implies students' attention languishing on the one hand ("we don't pay attention any more", "we drop behind with learning"), and it leads to different forms of offence ("disrespect towards the teacher", "if jest turns into scoffing, it is no longer funny but hurtful"), even conflicts or negative consequences ("we get bad marks", "we are sent out from class", "we respond orally or write a test", "we get admonition", "we are registered in the entry of discipline", "our mark for conduct is lowered") on the other. From this latter set of responses, we can also deduce that there is a wide range of available tools for maintaining discipline and moderation in the classroom.

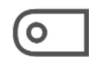

HUMOUR in the classroom

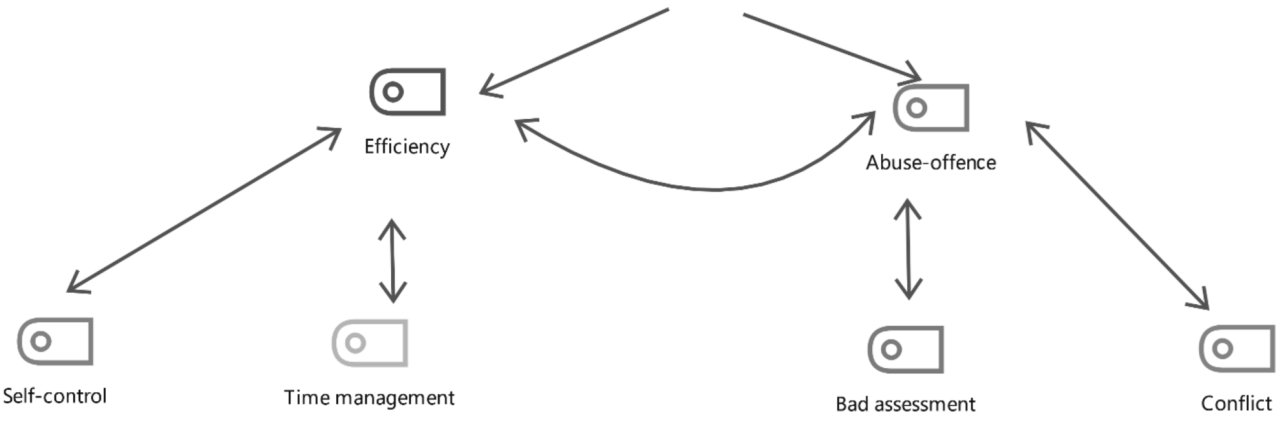

Figure 3. Negative effects of classroom humour (term web) 
The answers provided by respondents make it clear that humour is a core value in their communities, with lots of positive effects. At the same time, these answers point out a variety of tools being used to maintain moderation in classroom interaction.

In a subsequent part of the test, we were curious about the types of events which are considered to be humorous by students. The majority of experiences evoked $(60 \%)$ is related to some humorous event, such as changing classrooms on April's Fool Day, students discovered while cheating or falling off their chair, etc. This aspect is closely related to the characteristics specific of their age (idiosyncrasy).

Another subgroup (around 20\%) evoked humorous experiences related to learning topics, for example, the life and habits of interesting tribes, norms of behaviour characteristic of different cultures or peculiar religious customs and students' comments related to them.

A third group brought up as an example some element of linguistic humour $(20 \%)$. These examples range from events of mispronunciation (e.g. "herbal predicate" instead of "verbal predicate") to saying something foolish or embarrassing (e.g. "I called the teacher Mom"), but also funny remarks or irony in the teachers' discourse ("try to answer the question... we are not at the theatre", during an explanation: "it is not the same to walk on or to be walked on") as well as teachers' ways of addressing their students ("my dears", "youngsters").

The fact that respondents defined a very subtle difference between humour and mockery deserves a special attention. The moral of a well-known Hungarian proverb („minden viccnek fele való”; in free English translation: "half of every joke is true”) is mentioned quite often, referring to the constructive nature and positive effect of humour. Due to its high frequency, the aforementioned proverb, in its essence, can be interpreted as a cultural code, but it also refers to the value of humour often associated with wittiness (i.e. Sekler wittiness), with intelligence and the feeling of belonging to a community since the foundation of understanding and interpreting humorous situations is common knowledge and experience as well as a shared system of norms. At the same time, mockery can be interpreted as a tool for exclusion.

Here are some remarks of the respondents, comparing humour and mockery: (1) in humorous situations, we "laugh together"; (2) in mockery, we "laugh at someone and not with someone"; (3) "in humorous contexts, we laugh at the situation itself; in mockery, we dispraise the person"; (4) "humour has its boundaries; beyond those boundaries, we are dealing with mockery"; (5) in humorous situations, "everyone laughs"; in the case of mockery, "only some"; (6) in humorous situations, "we laugh at the situation"; in the case of mockery, "we laugh at people". The statements in 1-6 illustrate that according to the norms of the communities under discussion humour is interpreted as a positive life experience and a positive human characteristic, often perceived as constructive criticism. Meanwhile, everything else beyond the boundaries of the term humour could be perceived as hurtful, offensive, stigmatizing. 
Returning to the atmosphere of humour, the last question students had to respond to referred to students' judgements of the main characteristics related to the profile of a humorous teacher. The answers provided by respondents have been interpreted according to our primary codes and are displayed in Table 3 below as well as in the term web in Figure 4.

Table 3. What is a humorous teacher like?

\begin{tabular}{llc}
\hline Code System & & Frequency \\
\hline Code System & & 143 \\
\hline & Teacher Profile & 0 \\
\hline & Perform & 16 \\
\hline & & Great sense of humour \\
\hline & $\begin{array}{l}\text { Creates humorous } \\
\text { situations }\end{array}$ & 49 \\
\hline & Teaching & 24 \\
\hline & Understands humorous situations & 32 \\
\hline
\end{tabular}
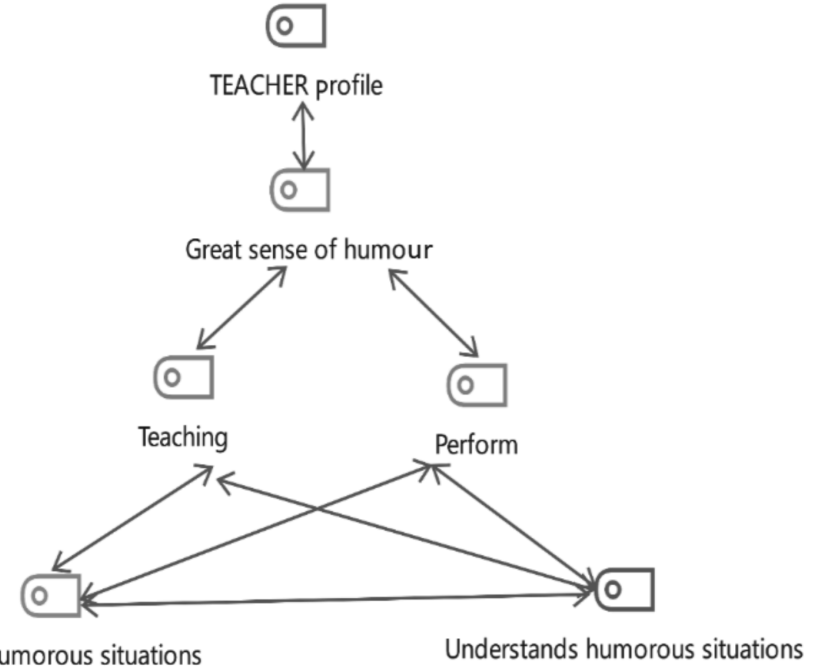

Creates humorous situations

Understands humorous situations

Figure 4. The profile of the humorous teacher (term web)

The personality of the teacher, their individual traits are extremely important from students' perspective since, according to students' judgement, the sense of humour has an effect on everything, as displayed in the term web designed based on student responses. In a learning environment or explanation built around humour, beyond laughter, we can also observe features such as playfulness, being dynamic, agile, flexible, nice, and funny. Throughout everyday classwork, funny teachers are jolly, cheerful, and youthful, provide explanation that is easily retained, "energize" 
and "put students in a good mood", or "crack a joke without exaggerating" so that "everyone understands their explanations and everyone enjoys their classes". They understand humorous situations and have the appropriate attitude towards them. Thus, humorous teachers are "not ones that students laugh about". They deliver their lessons with ease, without being monotonous, can "think with students' minds", and students enjoy their classes. Based on students' responses, the profile of the humorous teacher highlights first of all teachers' playfulness, their dynamic nature and creative presence as well as the positive feelings they induce.

\section{Conclusions}

In this article, we have undertaken to map the judgements configured by microcommunities, such as school communities, since, due to the quality time spent there, school plays an important role in determining people's personalities. This unique location offers a specific interpretation of the discourse of humour, based on local and individual life experiences. In this light, classroom humour can be captured in different forms: humorous situations, humorous topics, or humorous linguistic ingenuity. These situations are connected with positive learning experiences, embedded in flexibility and creativity. At the same time, according to the respondents' judgement, humour encountered in learning situations can be determined first of all by various individual attitudes, which include playfulness, flexibility, and dynamic character. These situations are determining factors of the group dynamics due to their team-building feature.

Concluding, based on the responses provided by students, we can state that in the sample we have analysed the discourse of humour carries the following functions: (a) it supports the initiation of a positive, supportive emotional atmosphere; (b) it strengthens the cohesion of the community; (c) it promotes the efficiency of teaching through its playfulness, dynamic nature, creativity, and critical thinking; (d) it boosts teachers' credibility and intensifies interpersonal relations.

Based on the data of the empirical research, it can be stated that the humour of classroom conversations is generated by spontaneous speech situations. This humour fulfils a series of positive roles on different levels of teacher-student collaboration. In this configuration, classroom humour acquires a specific meaning: it denotes all those exhilarated situations which lead to common experiences of meaning, of being together and in which playfulness, surprise, emotional transformation, and creativity are present at the same time. 


\section{References}

Bagdi, Emőke-Pap, János. 2011. Ma még nem nevettem [I Have Not Laughed Today Yet]. Budapest: Kulcslyuk.

Bannink, Anne-Dam van Jet. 2006. A dynamic discourse approach to classroom research. Linguistics and Education 17: 283-301.

Berger, Arthur Asa. 2017. An Anatomy of Humour. London-New York: Routledge.

Deiter, Ron. 2000. The use of humour as a teaching tool in the college classroom. NACTA Journal 44(2): 20-28.

Douglas, Harris N.-Tim R. Sass. 2009. What Makes for a Good Teacher and Who Can Tell? National Center for Analysis of Longitudinal Data in Education Research, Urban Institute. https://www.urban.org/sites/default/files/ publication/33276/1001431-What-Makes-for-a-Good-Teacher-and-Who-CanTell-.PDF (Last accessed: 5 June 2020).

Ezechil, Liliana. 2002. Comunicarea educațională în context şcolar [Educational Communication in School Context]. Bucharest: Editura Didactică şi Pedagogică.

Harklau, Linda. 2005. Ethnography and ethnographic research on second language teaching and learning. In Eli Hinkel (ed.), Handbook of Research in Second Language Teaching and Learning, 179-194. Mahwah, New Jersey: Lawrence Erlbaum Associates.

Hinkel, Eli. 2006. Classroom talk. In Keith Brown (ed.), Encyclopedia of Language and Linguistics ( $2^{\text {nd }}$ edition), 579-583. Oxford: Elsevier Science.

Lafollette, Hugh-Niall Shanks. 1993. Belief and the basis of humor. American Philosophical Quarterly 30(4): 329-339.

Levine, S. Glenn. 2011. Code Choice in the Language Classroom. Bristol-BuffaloToronto: Multilingual Matters.

Mackey, Alison-Susan M. Gass. 2005. Second Language Research: Methodology and Design. London: Lawrence Erlbaum Associates Publishers.

Martin, Rod A. 2007. The Psychology of Humor. An Integrative Approach. Burlington, MA, USA: Elsevier Academic Press.

Medgyes, Péter. 2018. A nyelvtanulás - tréfadolog [Language learning - A funny thing]. Modern Nyelvoktatás 24(1): 47-58.

Morreall, John. 2016. Philosophy of humour. In Edward N. Zalta (ed.), The Stanford Encyclopedia of Philosophy. https://plato.stanford.edu/archives/win2016/ entries/humor/ (Last accessed: 5 June 2020).

Orme, Michael, E. J. 1986. Uses of humour in instruction. NACTA Journal 30(3): 13-17.

Raskin, Victor. 1985. Semantic Mechanisms of Humour. Boston: Reidel.

Ribot, Théodule. 2012 [1900]. Psychology of the Emotions. Whitefish: Kessinger Publishing. 
Sántha, Kálmán. 2013. Multikódolt adatok kvalitatív elemzése [Qualitative Analysis of Multi-Coded Data]. Budapest: Eötvös József.

- 2015. Trianguláció a pedagógiai kutatásban [Triangulation in Pedagogical Research]. Budapest: Eötvös József.

Tutunea, Gabriela. 2020. Humour in the classroom. In Tódor, Erika-Mária-Enikő Pál-Zsuzsanna Dégi-Vilma Mihály (eds), Spații intermediare/Spaces in between, 211-227. Cluj-Napoca: Scientia.

Veatch, Thomas C. 1998. A theory of humour. International Journal of Humour Research 11(2): 161-215. https://www.degruyter.com/view/journals/humr/11/2/ article-p161.xml (Last accessed: 5 June 2020).

Wulf, Douglas. 2010. A humour competence curriculum. TESOL Quarterly 44(1): 155-168.

\section{Dictionaries}

A magyar nyelv értelmezó szótára [The Explanatory Dictionary of the Hungarian Language]. https://www.arcanum.hu/hu/online-kiadvanyok/Lexikonok-amagyar-nyelv-ertelmezo-szotara-1BE8B/ (Last accessed: 5 June 2020).

Cambridge Dictionary. https://dictionary.cambridge.org/ (Last accessed: 5 June 2020).

Dicționar explicativ al limbii române [The Explanatory Dictionary of the Romanian Language]. https://dexonline.ro/ (Last accessed: 5 June 2020).

Rey, Alain (ed.). 1997. Dictionnaire de la Langue Française [The Dictionary of the French Language]. Paris: Microrobert. 